\title{
PENGARUH CITRA PASAR TRADISIONAL TERHADAP KEBERHASILAN CITY BRANDING KOTA SOLO
}

\author{
Shinta Permana Putri \\ Institut Teknologi Bandung \\ Jl. Ganesha No 10 Bandung 40132 - Telp (022) 2500935 \\ E-mail: shintapermanaputri@gmail.com
}

\begin{abstract}
ABSTRAK
Citra positif kota yang kuat berperan dalam menentukan keberhasilan city branding. Citra positif kota ini mempermudah terbentuknya keunggulan kompetitif. Citra tersebut dapat berkomunikasi melalui berbagai cara, salah satunya melalui budaya. Penelitian ini dilakukan untuk mengetahui pengaruh adanya citra pasar tradisional sebagai bagian dari budaya Kota Solo dalam menarik penduduk dan wisatawan untuk tetap tinggal dan berkunjung. Regresi linear berganda digunakan untuk menguji dan menemukan faktor citra pasar tradisional yang mempengaruhi keberhasilan city branding. Penelitian menggunakan 120 sampel yang terdiri dari penduduk dan wisatawan. Pengambilan sampel dilakukan dengan menggunakan metode combined sampling. Hasil penelitian menunjukkan bahwa terdapat pengaruh yang kuat antara citra pasar tradisional terhadap keberhasilan city branding. Pasar tradisional terbukti mampu mempengaruhi terbentuknya citra positif Kota Solo meskipun bukan menjadi satu-satunya penentu keberhasilan city branding. Faktor pengetahuan tentang pasar tradisional dan faktor pertimbangan berkunjung ke pasar tradisional menjadi faktor yang signifikan berpengaruh dalam menarik penduduk dan wisatawan untuk tetap tinggal dan berkunjung ke Kota Solo
\end{abstract}

Kata Kunci : pasar-tradisional, budaya, citra-kota, city-branding.

\section{ABSTRACT}

The positive image of the city plays a strong role in determining the success of city branding. The positive image of the city makes it easier to form competitive advantages. These city images can be communicated in various ways, and one of them through culture. This research was conducted to determine the influence of the image of traditional markets as a part of the culture of Solo in attracting residents and tourists to stay and visit. Multiple linear regression is used to test and find traditional market image factors that influence the success of city branding. The study used 120 samples consisting of residents and tourists. Sampling uses the combined sampling method. The results of the study show that there is an influence between the traditional market image on the success of city branding. Traditional markets have been proven to be able to influence the formation of a positive image of Solo although it is not the only determinant of the success of city branding. Traditional market condition and traditional market reputation are significant factors in attracting residents and tourists to stay and visit Solo.

Keywords: traditional market, culture, city image, city branding.

\section{PENDAHULUAN}

City branding merupakan sebuah strategi suatu kota untuk mencapai keunggulan kompetitif (Kavaratzis, 2004). Keberadaan city branding dapat meningkatkan daya saing suatu kota. Daya saing inilah yang dapat digunakan suatu kota untuk berkompetisi di era global. Di sisi lain, citra positif kota yang kuat dapat mempermudah terbentuknya keunggulan kompetitif tersebut (Rainisto, 2003). Citra ini dapat berkomunikasi melalui tiga strategi yakni primer (aspek fisik), sekunder (media periklanan), dan tersier. Dalam kasus kota-kota tertentu di dunia, budaya sebagai bagian komunikasi primer citra kota memiliki peran utama dalam mendukung city branding (Bıçakç1, 2012). Dengan begitu, keduanya saling berkaitan.
Solo menjadi salah satu kota yang menggunakan budaya sebagai identitasnya. Budaya kota ini digunakan untuk menarik penduduk dan pengunjung. Beberapa perwujudan budaya tersebut antara lain Keraton Surakarta, tradisi, ritual, keris, gamelan, batik, bahasa jawa, keroncong, seni tari, corak bangunan hingga karakter masyarakat jawa yang ramah dan sopan. Keberadaan pasar tradisional juga dapat dipandang sebagai aset budaya suatu kota. Keberadaan pasar merupakan syarat bagi keberadaan suatu keraton di Jawa. Menurut Catur Gatra Utama, pasar tradisional merupakan simbol penghidupan.

Budaya sebagai salah satu media komunikasi primer seharusnya dapat memperkuat 
citra positif kota dan mendorong keberhasilan city branding. Namun, pada kenyataannya pasar tradisional sebagai salah satu bentuk perwujudan budaya tidak selalu dapat membentuk citra positif yang kuat pada setiap kota. Keberadaan pasar tradisional sebagai cirikhas atau ikon suatu kota tidak selalu mampu menarik penduduk untuk tinggal maupun menarik wisatawan untuk berkunjung dalam suatu kota. Oleh sebab itu masih diperlukannya penelitian terkait pengaruh citra pasar tradisional terhadap keberhasilan city branding.

\section{TINJAUAN PUSTAKA}

\section{Citra Kota}

Citra kota dapat diartikan sebagai sejumlah pengetahuan, perasaan, pemikiran, pengalaman dan kesan unik seseorang terhadap suatu kota yang terbangun melalui beragam proses aktivitas panjang (Rainisto, 2003; Yananda dan Salamah, 2014). Citra ini bertujuan sebagai bentuk respon akan adanya kompetisi antarkota di era globalisasi (Braun dkk, 2014). Rainisto (2003) dan Avraham dan Ketter (2008) menambahkan apabila satu kota memiliki citra positif yang kuat dan dikombinasikan dengan upaya pemasaran kota yang baik maka kota tersebut dapat dengan mudah membentuk keunggulan kompetitif (Rainisto, 2003; Avraham dan Ketter, 2008; Anholt, 2009). Keunggulan kompetitif ini yang nantinya berkontribusi dalam meningkatkan daya saing kota (Avraham dan Ketter, 2008).

Citra suatu kota dapat berkomunikasi melalui berbagai bentuk seperti lingkungan fisik, penyenggaraan acara seperti musik, kesenian, dan olahraga maupun melalui tokoh terkenal yang berasal dari kota tersebut (Dinnie, 2011; Kavaratzis, 2004; Kavaratzis dan Ahworth, 2005). Selain itu, aspek budaya dalam bentuk sebuah fasilitas, penyelenggaraan acara, arsitektur, dan sejarah perkotaan juga turut memainkan peran penting dalam pembentukan dan penguatan citra kota (Bıçakçı, 2012). Kavaratziz (2004) dan Braun (2014) merangkum hal tersebut menjadi tiga pilihan komunikasi citra kota yang terdiri dari komunikasi primer, sekunder, dan tersier.

Citra suatu kota akan terbangun apabila konsep identitas yang melekat pada kota tersebut jelas (Rainisto, 2003). Citra ini terbentuk melalui empat komponen (Kavaratzis, 2008; Gartner, 1994) yakni kognitif (apa yang seseorang ketahui tentang suatu tempat), afektif (bagaimana seseorang merasakan suatu tempat), evaluatif (bagaimana seseorang menilai suatu tempat atau penduduknya), dan behavioural (apakah seseorang mempertimbangkan untuk tetap tinggal/bekerja/berkunjung/berinvestasi di suatu tempat).

\section{City Branding}

City branding merupakan strategi yang tepat dalam mencapai keunggulan kompetitif untuk memasarkan kota (Kavaratzis, 2004). Branding dipercaya menjadi cara yang terbaik dalam mempengaruhi persepsi dan citra tentang sebuah termasuk sebuah kota (Kavaratzis dan Ashworth, 2005). Tujuan utamanya yakni untuk meningkatkan daya tarik suatu kota, mencapai keunggulan kompetitif secara regional dan internasional, memperkuat reputasi kota dan identitasnya yang meningkatkan kepentingan ekonominya (Rainisto, 2003; Rehan, 2013).

Keberhasilan city branding ditentukan oleh kemampuannya dalam menarik penduduk dan pengunjung (Moilanen and Rainisto, 2009). Kesenangan dan kepuasan mereka menjadi tujuan yang paling utama dalam upaya memasarkan kota melalui city branding (Dinnie, 2011; Kavaratzis, 2004; Yananda and Salamah, 2014). Dengan begitu, keberhasilannya sangat ditentukan oleh persepsi pengunjung dan juga wisatawan. Keberhasilan tersebut juga dapat diukur menggunakan Hexagon City Brand Index yang terdiri dari:

a. The Presence, menekankan pada aspek status dan kedudukan yang dimiliki suatu kota hingga pada taraf internasional

b. The Potential, menekankan pada kemampuan suatu kota dalam membentuk presepsi kesenangan dan ketertarikan seseorang terhadap aspek fisik suatu kota

c. The People, menekankan pada kemampuan suatu kota dalam menyediakan peluang ekonomi dan pendidikan kepada para pengunjung, pelaku bisnis, dan pendatang.

d. The Prerequisites, menekankan pada kemampuan suatu kota dalam menciptakan gaya hidup yang bersemangat bagi orang yang tinggal di dalamnya

e. The Pulse, menekankan keramahan dan keterbukaan warga, keamanan kota, dan kemampuan suatu kota dalam menciptakan komunitas yang kondusif untuk pertukaran bahasa dan budaya

f. The Place, menekankan pada kemampuan kota dalam menyediakan pelayanan dasar yang berhubungan dengan tingkat kepuasan mereka (Anholt, 2006). 


\section{METODE PENELITIAN}

\section{Lokasi Penelitian}

Penelitian ini difokuskan pada 3 kecamatan di Kota Solo yakni Banjarsari, Pasar Kliwon, dan Jebres. Tiga pasar tradisional di Solo yakni Pasar Gedhe, Pasar Klewer, dan Pasar Triwindu terpilih menjadi unit amatan spesifik dalam melihat pengaruh citra pasar tradisional dalam mendukung keberhasilan city branding Kota Solo. Ketiga pasar ini menjadi unit amatan karena memenuhi kriteria keunikan pasar tersendiri. Keunikan ini dilihat dari nilai kesejarahannya, kekhasan produk, dan juga klasifikasi pengunjung. Keunikan ini dianggap paling mencitrakan pasar tradisional di Kota Solo.

\section{Variabel Penelitian}

Variabel dan indikator yang digunakan dalam penelitian ini ditentukan melalui deduksi teori. Variabel dan indikator penelitian ini dijelaskan pada Tabel 1 .

\section{Tabel 1. Variabel dan Indikator Penelitian}

\begin{tabular}{|c|c|}
\hline Variabel & Indikator \\
\hline \multicolumn{2}{|l|}{ Citra Pasar Tradisional } \\
\hline Pengetahuan keberadaan pasar & Tingkat pengetahuan tentang keberadaan pasar \\
\hline Ketenaran pasar & Persepsi ketenaran pasar \\
\hline Pemahaman tentang pasar & Tingkat pemahaman tentang pasar \\
\hline Kondisi FisiK Pasar & Persepsi kondisi pasar \\
\hline Pelayanan Pasar & Persepsi pelayanan pasar \\
\hline Pengalaman Berkunjung & Tingkat intensitas berkunjung \\
\hline Kelengkapan produk & Persepsi kelengkapan produk \\
\hline Harga komoditas & Persepsi harga komoditas pasar \\
\hline Suasana pasar & Persepsi suasana pasar \\
\hline Minat berkunjung & Tingkat pertimbangan berkunjung \\
\hline \multicolumn{2}{|l|}{ Keberhasilan City Branding } \\
\hline Keakraban terhadap kota & Tingkat keakraban dengan kota \\
\hline Pengetahuan terhadap kota & Tingkat pengetahuan tentang kota \\
\hline Pengalaman berkunjung & Tingkat keinginan untuk tinggal lebih lama \\
\hline Ketenaran kota & Tingkat ketenaran kota \\
\hline Kesenangan terhadap aspek fisik kota & Tingkat kesenangan terhadap kota \\
\hline Kekaguman/ketertarikan terhadap aspek fisik kota & Tingkat ketertarikan terhadap kota \\
\hline Peluang ekonomi & Persepsi peluang ekonomi yang diberikan kota \\
\hline Peluang pekerjaan & Persepsi peluang pekerjaan yang ditawarkan kota \\
\hline Peluang edukasi & Persepsi peluang edukasi yang diberikan kota \\
\hline Kesesuaian menjadi tempat usaha & Tingkat kecocokan sebagai tempat usaha \\
\hline Peluang wisata & Tingkat kecocokan sebagai tempat wisata \\
\hline Peluang terselenggaranya acara yang menarik & Tingkat kecocokan sebagai tempat penyelenggara acara \\
\hline Kemudahan menemukan hal yang menarik & $\begin{array}{l}\text { Tingkat kemudahan menemukan pengalaman menarik di } \\
\text { kota }\end{array}$ \\
\hline Kemampuan membangkitkan kehidupan yang bersemangat & $\begin{array}{l}\text { Tingkat kemampuan membangkitkan kehidupan yang } \\
\text { bersemangat }\end{array}$ \\
\hline Kemampuan dalam menciptakan tambahan pengalaman & Tingkat kemampuan menambah pengalaman \\
\hline Keramahan dan keterbukaan warga & Tingkat keramahan dan keterbukan penduduk \\
\hline Keamanan kota & Persepsi sebagai tempat yang aman \\
\hline $\begin{array}{l}\text { Peluang terciptanya komunitas yang kondusid untuk } \\
\text { pertukatan pengetahuan }\end{array}$ & $\begin{array}{l}\text { Tingkat kemampuan menciptakan hubungan relasi dan } \\
\text { kekerabatan }\end{array}$ \\
\hline Kepuasan terhadap pelayanan kota & Tingkat kepuasan terhadap pelayanan kota \\
\hline Kemampuan mengakomodir kebutuhan & $\begin{array}{l}\text { Persepsi sebagai tempat yang menyediakan fasilitas hidup } \\
\text { lengkap }\end{array}$ \\
\hline
\end{tabular}

\section{Populasi, Sampel, dan Metode Sampling}

Populasi dalam penelitian ini adalah jumlah penduduk pada tiga kelurahan di Kota Solo yang berjumlah 60.238 jiwa. Populasi ini ditetapkan melalui beberapa tahap. Pertama penetapan populasi penduduk dilakukan dengan menyeleksi kecamatan-kecamatan di Kota Solo yang dianggap memiliki keunikan pasar tradisional. Kedua, menyeleksi kelurahan dari kecamatankecamatan yang telah terpilih sebelumnya. Kriteria yang digunakan yakni kelurahan yang 
memiliki jumlah pasar tradisional terbanyak di dalam kecamatan- kecamatan terpilih. Selain itu, populasi juga berasal dari wisatawan atau pengunjung Kota Solo yang berjumlah 371.000 pengunjung. Jumlah ini ditetapkan melalui perhitungan langsung di lapangan. Jumlah sampel yang digunakan dalam penelitian ini sebanyak 120 sampel dengan tingkat confidence level $90 \%$. Metode sampling yang digunakan yakni combined sampling. Combined sampling ini diterapkan secara berbeda anatara penduduk dan wisatawan. Untuk sampel penduduk digunakan Proportional Multistage Sampling. Untuk sampel wisatawan digunakan Proportional Accidental Sampling

\section{Metode Analisis Data}

Hasil pengumpulan data dianalisis menggunakan metode statistik inferensial dan deskriptif dengan bantuan perangkat lunak SPSS. Teknik inferensial yang digunakan adalah regresi linier berganda. Statistik ini digunakan untuk menguji pengaruh antara citra pasar tradisional terhadap keberhasilan city branding serta menemukan faktor-faktor yang mempengaruhinya. Sebelum dilakukan pengujian statistik, langkah pertama yang dilakukan yaitu memberikan skor / kode variabel. Analisis faktor juga digunakan untuk memperkecil korelasi antara variabel yang ada dan juga meringkas variabel yang ada. Beberapa uji asumsi juga dilakukan untuk mengetahui kelayakan dalam menggunakan regresi linier berganda. Selanjutnya, statistik deskriptif dilakukan untuk memberikan makna pendukung. Hasil statistik ini dapat digunakan sebagai analisis pendukung dalam intrepretasi hasil pengolahan statistik sebelumnya.

\section{HASIL DAN PEMBAHASAN}

\section{1.) Pengaruh Citra Pasar Tradisional terhadap Keberhasilan City Branding Kota Solo}

Uji analisis faktor dilakukan pertama kali sebelum melakukan uji regresi linear berganda. Uji ini dilakukan untuk membentuk faktor citra pasar tradisional baru berdasarkan sejumlah variabel penyusunnya. Variabel citra pasar tradisional yang berkorelasi kuat dengan variabel citra pasar tradisional yang lain cenderung akan mengelompok menjadi faktor baru pembentuk citra pasar tradisional. Berdasarkan hasil analisis faktor diperoleh tiga faktor baru terkait citra pasar tradisional. Komposisi tiga faktor ini ditunjukkan dalam Tabel 2 dan Tabel 3.
Table 2. Output Pembentukan Faktor Citra Pasar Tradisional

\begin{tabular}{c|c|c|c}
\hline & \multicolumn{3}{|c}{ Component } \\
\cline { 2 - 4 } & $\mathbf{1}$ & $\mathbf{2}$ & $\mathbf{3}$ \\
\hline CT9 &, 873 &, 125 &, 073 \\
CT10 &, 852 &, 098 &, 124 \\
CT4 &, 729 &, 173 &, 164 \\
CT6 &,- 079 &, 780 &,- 155 \\
CT1 &, 093 &, 707 &, 304 \\
CT2 &, 384 &, 652 &, 176 \\
CT7 &, 115 &, 612 &, 344 \\
CT3 &, 296 &, 538 &, 626 \\
CT5 &, 229 &,- 071 &, 737 \\
CT8 &, 025 &, 129 &, 718 \\
\hline
\end{tabular}

Table 3. Hasil Pembentukan Faktor Citra Pasar Tradisional Berdasarkan Analisis Faktor

\begin{tabular}{|c|c|}
\hline $\begin{array}{l}\text { Faktor Citra Pasar } \\
\text { Tradisional (Baru) }\end{array}$ & $\begin{array}{c}\text { Variabel Penyusun Citra } \\
\text { Tradisional }\end{array}$ \\
\hline Kondisi pasar (KP) & $\begin{array}{l}\text { Kondisi fisik pasar (CT4), } \\
\text { suasana pasar (CT9, minat } \\
\text { berkunjung (CT10) }\end{array}$ \\
\hline Reputasi Pasar (RP) & $\begin{array}{l}\text { Pengetahuan keberadaan pasar } \\
\text { (CT1), ketenaran pasar (CT2), } \\
\text { pemahaman tentang pasar } \\
\text { (CT3), pengalaman } \\
\text { berkunjung } \\
\text { kelengkapan produk (CT7) }\end{array}$ \\
\hline Pelayanan Pasar (PP) & $\begin{array}{l}\text { Pelayanan pasar (CT5), harga } \\
\text { produk (CT8) }\end{array}$ \\
\hline
\end{tabular}

Tiga faktor citra pasar tradisional yang terbentuk ini menjadi input dalam analisis regresi linear berganda. Tiga faktor baru ini menjadi variabel independen yang tidak lagi memiliki korelasi satu sama lain. Dalam penelitian ini, analisis regresi dilakukan dalam dua kali proses. Pada proses regresi yang pertama masih ditemukan salah satu faktor citra pasar tradisional yang tidak signifikan.

Berdasarkan dua model regresi yang terbentuk dilakukan seleksi pemilihan model terbaik. Tujuan seleksi ini adalah untuk mendapatkan interpretasi yang paling baik terkait pola hubungan yang terbentuk antara citra pasar tradisional dengan keberhasilan city branding. Model regresi kedua menjadi model yang terpilih. Model terpilih ini dianggap layak menjadi prediktor karena telah memenuhi persyaratan uji asumsi klasik dan juga uji kelayakan model. Model ini menghasilkan output yang ditunjukkan Tabel 4.

Table 4. Output Model Regresi

\begin{tabular}{ccccc}
\hline $\mathbf{R}$ & $\begin{array}{c}\mathbf{R} \\
\text { Square }\end{array}$ & $\begin{array}{c}\text { Adjuste } \\
\mathbf{d} \mathbf{R} \\
\text { Square }\end{array}$ & $\begin{array}{c}\text { Std Error } \\
\text { of the } \\
\text { Estimates }\end{array}$ & $\begin{array}{c}\text { Durbin } \\
\text { Watson }\end{array}$ \\
\hline, 613 &, 376 &, 359 & 5,53096 & 1,800 \\
\hline
\end{tabular}


Angka 0,371 pada koefisien determinasi $\left(\mathrm{R}^{2}\right)$ mengartikan bahwa $37,1 \%$ variasi dalam variabel keberhasilan city branding dapat diterangkan oleh variabel citra pasar tradisional. Koefisien determinasi (R.Square) yang masih rendah mengindikasikan bahwa variabel citra pasar tradisional belum mampu sepenuhnya mempengaruhi adanya keberhasilan city branding suatu kota. Dalam hal ini, pasar tradisional bukan menjadi satu-satunya penentu dari adanya keberhasilan city branding dari suatu kota..

Atribut reputasi dan atribut kondisi yang terpersepsikan dari pasar tradisional ternyata belum mampu menarik penduduk dan wisatawan untuk tinggal dan berkunjung di Kota Solo secara optimal. Hal ini wajar saja terjadi karena pasar tradisional hanya merupakan bagian kecil dari pembentuk citra suatu kota. Pasar tradisional hanya merupakan salah satu dari sekian banyak aspek fisik kota yang dapat dijadikan sebagai media komunikasi primer suatu kota.

Adanya preferensi lain terhadap Solo sebagai tempat tinggal dan destinasi wisata menjelaskan kecilnya peran citra pasar tradisional dalam mendukung keberhasilan city branding. Bagi penduduk, ikatan emosial terhadap Kota Solo sebagai kota kelahiran, adanya ikatan kekeluargaan di Kota Solo, dan lingkungan yang nyamanlah yang menjadi pendorong utama preferensi penduduk memilih tinggal di Kota Solo. Bagi wisatawan, pendorong utama preferensi mereka berkunjung ke Solo dapat didorong oleh faktor kedekatan lokasi, harga yang murah, fasilitas yang lengkap, dan keragaman penyelenggaraan festival.

Berdasarkan model terpilih juga dapat dikatakan bahwa faktor reputasi pasar tradisional (RP) memiliki peran yang lebih besar dalam mendukung keberhasilan city branding di Kota Solo seperti yang ditunjukkan Tabel 5. Hal ini dapat terjadi karena atribut reputasi pasar tradisional (RP) memiliki peran pertama kali dalam membentuk ekspektasi seseorang tentang suatu tempat melalui proses kognitif yang mereka alami. Besarnya pengaruh faktor reputasi pasar dibuktikan dengan banyaknya pengunjung yang datang hanya karena tahu pasar itu terkenal.

Table 5. Output Model Regresi

\begin{tabular}{lccccc}
\hline \multirow{2}{*}{ Model } & \multicolumn{2}{c}{$\begin{array}{c}\text { Unstandardized } \\
\text { Coefficients }\end{array}$} & $\begin{array}{c}\text { Standardized } \\
\text { Coefficients }\end{array}$ & t & Sig \\
\cline { 2 - 6 } & B & Std. Error & Beta & & \\
\hline (Constant) & 67,608 &, 504 & & 134,03 &, 000 \\
Kondisi & 2,885 &, 507 &, 418 & 5,696 &, 000 \\
$\begin{array}{l}\text { Pasar } \\
\text { (KP) }\end{array}$ & 3,068 &, 507 &, 444 & 6,057 &, 000 \\
Reputasi & & & & & \\
Pasar (RP) & & & & & \\
\hline
\end{tabular}

Faktor kondisi pasar (KP) hanya merupakan faktor pendukung. Faktor ini dapat membentuk penilaian lanjutan setelah seseorang mengetahui, memahami, dan merasakan bagaimana pasar tradisional tersebut dicitrakan. Dalam hal ini pasar tradisional tidak hanya dipandang sebagai media komunikasi primer saja. Pada kenyataannya, pasar tradisional sebagai perwujudan infrastruktur fisik perdagangan dapat pula melebur menjadi media komunikasi sekunder melalui media yang merepresentasikannya. Selain itu pasar tradisional yang dikenal melalui cerita yang menyebar dari orang ke orang sebagai media komunikasi tersier citra kota. Ini dimungkinkan terjadi karena citra terbentuk oleh persepsi seseorang yang dipengaruhi oleh pengalamannya secara langsung maupun informasi yang datang dari luar diri orang tersebut (seperti cerita orang dan media yang merepresentasikannya).
Pengaruh citra pasar tradisional dapat dilihat dalam enam dimensi keberhasilan city branding yang ditunjukkan Gambar 1. Dalam gambar tersebut dapat diketahui beberapa hal terkait pengaruh citra pasar tradisional dalam enam dimensi keberhasilan city branding yakni:

1. Pasar tradisional yang menawarkan suasana etnis telah mempengaruhi presepsi positif responden bahwa Kota Solo memiliki banyak hal-hal menarik untuk ditonton dan dikunjungi sehingga dapat menambah pengalaman baru (dimensi pulse).

2. Pasar tradisional yang mencerminkan kegiatan masyarakat Kota Solo mempengaruhi presepsi yang positif bahwa Kota Solo memiliki penduduk yang ramah dan mudah bergaul sehingga menciptakan peluang terbentuknya hubungan relasi yang baru (dimensi people). 
3. Pasar tradisional yang menjadi sarana perdagangan mempengaruhi presepsi yang positif bahwa Kota Solo mampu mengakomodir kebutuhan sehari-hari baik bagi penduduk maupun wisatawan yang berkunjung (dimensi prerequisites).

4. Pasar tradisional yang merupakan salah satu bangunan bersejarah mempengaruhi presepsi yang positif bahwa Kota Solo memiiliki aspek fisik kota yang menarik untuk dikunjungi (dimensi place).

5. Pasar tradisional yang terkenal di berbagai media mempengaruhi presepsi yang positif bahwa Kota Solo adalah kota yang tenar (dimensi presence).

6. Namun, pasar tradisional ternyata hanya cukup mampu untuk mempengaruhi presepsi yang positif tentang kesempatan dan peluang yang ditawarkan Kota Solo seperti peluang edukasi, peluang ekonomi, peluang wisata, peluang tempat usaha, dan peluang penyelenggaraan festival (dimensi potential).

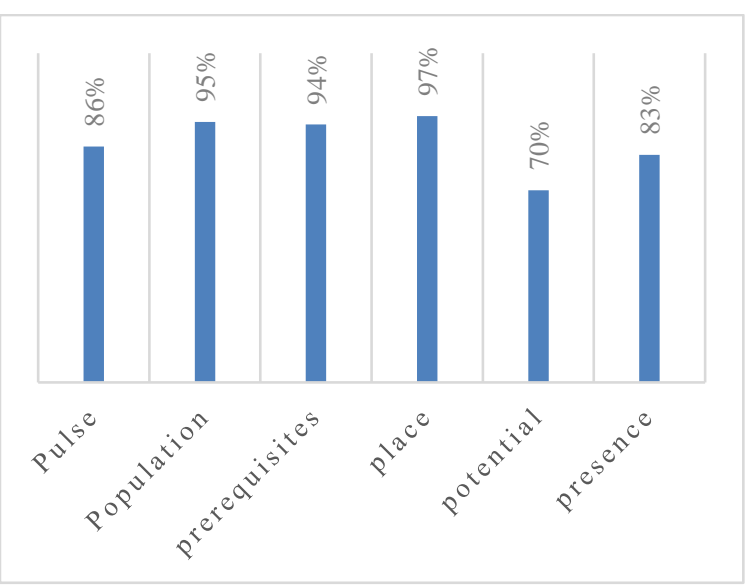

\section{Gambar 1. Pengaruh Citra Pasar Tradisional dalam Enam Dimensi Keberhasilan City Branding}

\section{2.) Pengaruh Citra Pasar Tradisional terhadap Keberhasilan City Branding Kota Solo}

Kedua faktor citra pasar tradisional yang signifikan dalam uji statistik, memiliki pengaruh yang berbeda dalam menentukan keberhasilan city banding bagi penduduk maupun wisatawan. Perbedaan pengaruh tersebut diduga disebabkan oleh perbedaan pemanfaatan dari pasar tradisional. Bagi penduduk, pasar tidak hanya merupakan tempat rekreasi tetapi juga untuk memenuhi kehidupan sehari-hari, berinteraksi sosial, bekerja, dan juga melestarikan budaya. Selain itu juga dipengaruhi oleh tingkat pemahaman tentang pasar. Menurut Gambar 2,
97\% penduduk memiliki proses pemahaman yang lebih tinggi dalam membentuk reputasi pasar di benaknya. Hal ini turut dipengaruhi oleh intensitas kunjungan. Delapan dari sepuluh penduduk pada Gambar 3 mengaku sering mengunjungi pasar karena lokasinya yang dekat.

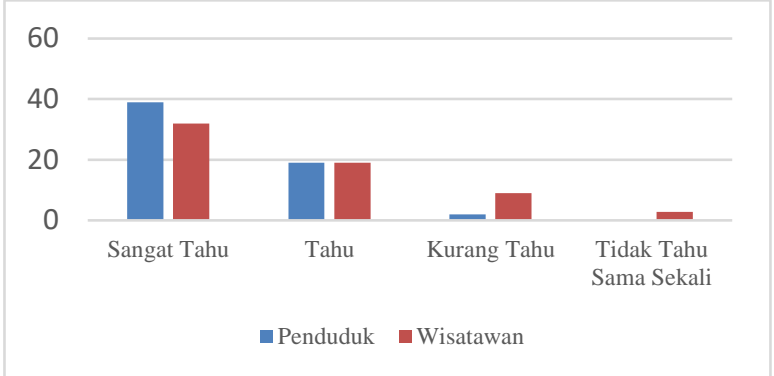

\section{Gambar 2. Pemahaman tentang Pasar Trandisional}

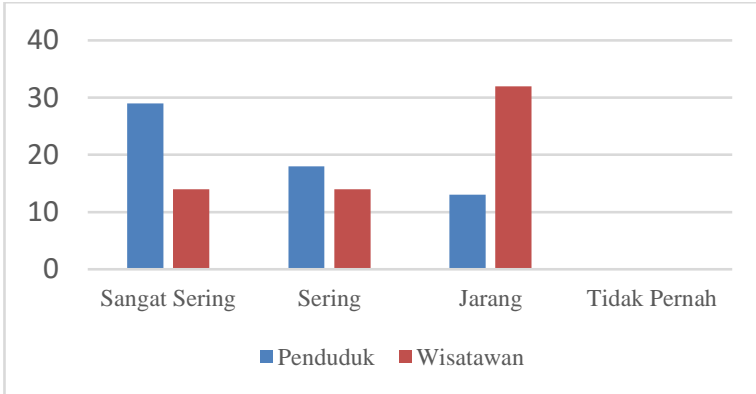

\section{Gambar 3. Intensitas dalam Mengunjungi Pasar Tradisional}

Wisatawan memiliki komitmen/minat yang lebih rendah dalam mengunjungi pasar tradisional jika dibandingkan dengan penduduk. Gambar 4 menunjukkan bahwa presentase keinginan wisatawan untuk berkunjung kembali ke pasar tradisional yang menurun pada angka $90 \%$. Meskipun begitu, $90 \%$ wisatawan yang ditunjukkan Gambar 5 menilai bahwa pasar tradisional tetap menarik untuk dikunjungi. Hal ini dipengaruhi oleh pengalaman visual wisatawan dalam membentuk persepsi terkait kondisi pasar.

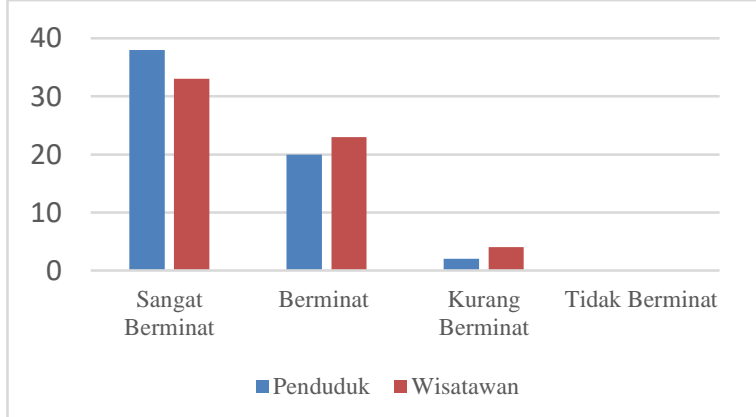

Gambar 4. Minat dalam Mengunjungi Pasar Tradisional 


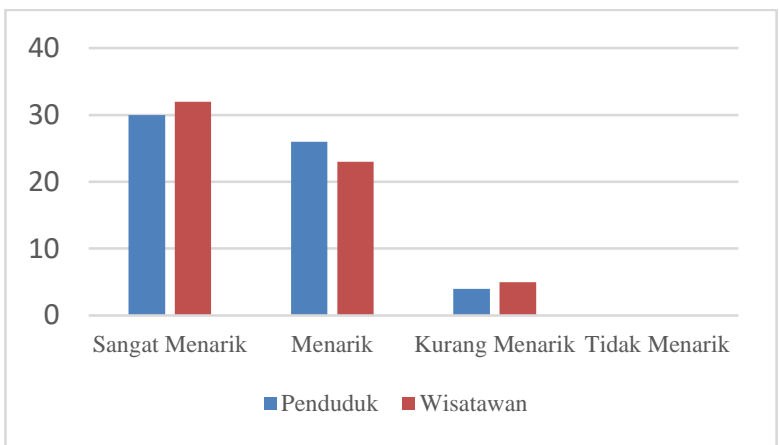

Gambar 5. Kemenarikan Pasar Tradisional

Bagi penduduk dan wisatawan, atribut reputasi merupakan atribut pendorong utama mereka untuk berkunjung. Dengan popularitas, ketenaran, dan nama baik pasar tradisional yang dipersepsikannya akan menumbuhkan rasa keingintahuan mereka untuk melakukan pengalaman berkunjung secara pribadi. Hal tersebut dilakukan meskipun mereka belum mengetahui bagaimana pasar tersebut menyediakan dan mewujudkan ekspektasi mereka. Atribut kondisi pasar tentunya menjadi atribut pendukung dalam memenuhi ekspektasi penduduk dan wisatawan tentang pasar tradisional. Atribut ini penting dalam menciptakan kepuasan dan kenyamanan mereka dalam rangka menjaga komitmen berkunjungnya ke pasar tradisional.

Berdasarkan presentase pengetahuan penduduk dan wisatawan tentang pasar-pasar tradisional di Kota Solo, maka dapat dipetakan pasar-pasar tradisional yang telah berhasil menjadi media city branding, pasar yang berpotensi akan tetapi belum dikembangkan sebagai media city branding dan pasar yang kurang berpotensi seperti yang ditunjukkan pada Gambar 6. Dalam hal ini Pasar Gedhe, Pasar Klewer, dan juga Pasar Triwindu tergolong sangat berpotensi dan telah berhasil menjadi media branding karena memiliki nilai ketradisionalan, kekhasan komoditas, aksesibilitas, jangkauan pelayanan, harga yang ditawarkan, dan penyelenggaraan festival yang menonjol. Dua puluh tiga pasar tradisional lain yang berpotensi menjadi media branding memiliki kekhasan komoditas, aksesibilitas, jangkauan pelayanan, harga yang ditawarkan, serta penyelenggaraan festival yang masih dapat dioptimalkan dalam upaya memasarkan kota.

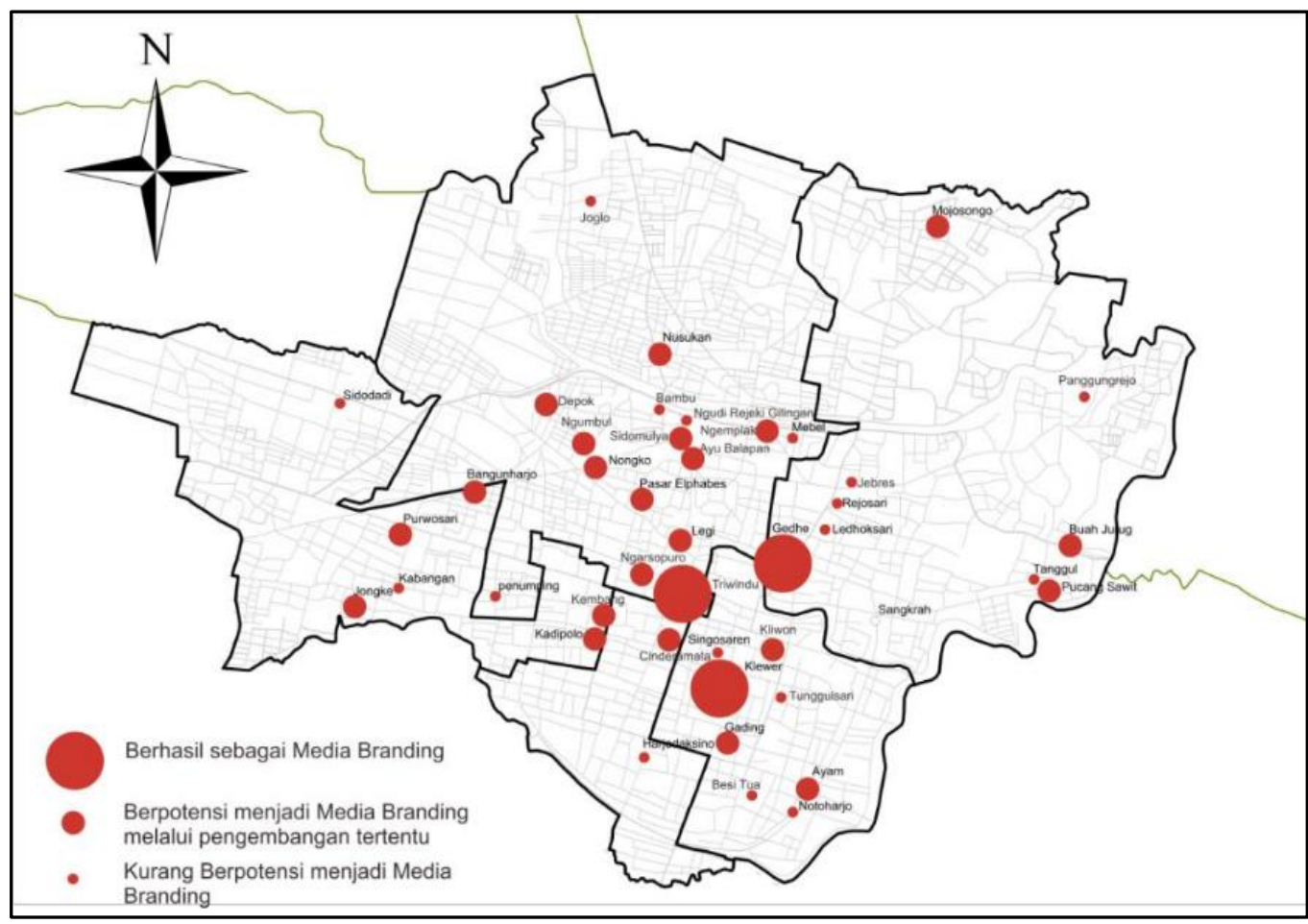

Gambar 6. Potensi Pengembangan Pasar Tradisional sebagai Media Branding

\section{KESIMPULAN}

Dalam penelitian ini dapat disimpulkan bahwa terdapat pengaruh citra pasar tradisional sebagai media komunikasi primer citra kota terhadap keberhasilan city branding yang ditunjukkan dengan koefisien determinansi $(R$ Square). Temuan ini sejalan dan memperkuat pendapat Braun (2014) dan Rainisto (2003) yang menemukan bahwa media komunikasi primer memang terbukti efektif menjadi strategi city branding. Namun pengaruh tersebut hanya bisa 
sedikit terjelaskan oleh variabel citra pasar tradisional yang ditunjukkan dari nilai $\mathrm{R}$ Square yang masih tergolong rendah. Hal ini sedikit mengevaluasi skema strategi dalam upaya city branding yang dikembangkan oleh Rehan (2014) yang menyebutkan bahwa bangunan bersejarah (historical bulding) mampu menjadi media yang handal. Pada kenyataannya, pasar tradisional sebagai perwujudan bangunan bersejarah masih perlu dioptimalisasi lagi perannya sebagai media branding.

Pasar tradisional sebagai citra kota belum mampu sepenuhnya mewakili penyederhaaan dari sekian banyak asosiasi dan informasi yang berhubungan dengan suatu kota seperti definisi citra kota yang dimaksudkan oleh Rainisto (2003). Hal ini sejalan dengan pendapat Dinnie (2011), OECD dalam Dinnie (2011), dan Bıçakçi (2012), upaya city branding melalui budaya tidak hanya dapat dilakukan melalui pasar tradisional saja. Masih banyak bentuk yang dapat dikembangkan dalam penelitian selanjutnya seperti bangunan- bangunan bersejarah, festival, tradisi/ritual, kesenian, dan sejarah yang dimiliki suatu kota. Upaya tersebut tentunya harus disinergikan juga dengan media komunikasi primer yang lain (Rehan, 2014 dan Kavaratzis, 2004), komunikasi sekunder maupun tersier citra kota melalui media periklanan secara terencana serta cerita yang menyebar dari orang ke orang (Kavaratzis, 2004).

Terdapat dua atribut pembentuk citra pasar tradisional yang secara signifikan mempengaruhi keberhasilan city branding tersebut. Kedua atribut itu yaitu atribut kondisi pasar dan juga atribut reputasi pasar tradisional. Kedua atribut ini memiliki pengaruh yang lebih besar dalam menentukan keberhasilan city branding pada penduduk dibandingkan pada wisatawan. Temuan ini sejalan dengan Dinnie (2011) yang menyampaikan bahwa dalam rangka menarik penduduk untuk tetap tinggal, suatu kota harus dapat mendukung komitmen jangka panjangnya melalui pemenuhan kebutuhan dasar sedangkangkan wisatawan bergantung pada persepsi kesenangan akan pengalaman visualnya.

\section{DAFTAR PUSTAKA}

Anholt, S. The Anholt-GMI City Brands Index: How The World Sees Rhe World's Cities. Place Branding. 2(1):18-31.

Anholt, S. 2009. Competitive Identity: The New Brand Management for Nations, Cities and Regions. UK. Palgrave Macmillan.

Ashworth, G dan Kavaratzis, M. 2010. Towards Effective Place Brand Management: Branding European Cities and Regions. UK. Edward Elgar Publishing Limited.

Avraham, E dan Ketter, E. 2008. Media Strategies for Marketing Place in Crisis: Improving the Image of Cities, Countries, and Tourist Destinations. UK. Elseiver Inc.

Bıçakçı, A. Branding The City Through Culture: Istanbul, European Capital Of Culture 2010. Human Science. 9(1):993-1006.

Braun, E., Eshuis, J. dan Klijn, E. The Effectiveness of Place Brand Communication. Cities. 41:64-70.

Dinnie, K. 2011. City branding Theory and Cases. UK. Palgrave Macmillan.

Gartner, W. Image Formation Process. Travel \& Tourism Marketing. 2(2):191-216.

Kavaratzis, M. From City Marketing to Citybranding: Towards a Theoritical Framework for Developing City Brands. Place Branding. 1(1): 58-73.

Kavaratzis, M dan Ashworth, G. City Branding: an Effective Assertion of Identity of a Transitory Marketing Trick. Place Branding. 96(5): 506-514.

Rehan, R. Urban Branding as an Effective Sustainability Tool in Urban Development. Housing and Building Research Center. 10: 222-230.

Rainisto, R. 2003. Success Factors of Place Marketing: A Study of Place Marketing Practices in Northem Europe and The United States. Hensinki University of Technology.

Riza, M. Culture and City Branding: Mega-Events and Iconic Building as Fragile Means to Brand The City. Social Science. 3(7): 269-274.

Yananda, M dan Salamah, U. 2014. Branding Tempat: Membangun Kota, Kabupaten, dan Provinsi Berbasis Identitas. Jakarta. Makna Informasi. 